\title{
Towards Growth of the Blue Economy in Zanzibar: Potentials and Challenges
}

\author{
Warda M. Mussa ${ }^{1}$, Zhang Jing ${ }^{* 2}$, \\ Abdulrahman S. Machochoki ${ }^{3}$ and Stephen J. Bakari ${ }^{4}$
}

1 UNEP-Tongji Institute of Environment for Sustainable Development College of Environmental Science and Engineering, Tongji University 1239 Siping Road, Shanghai 200092, China

2Institute of Environment Planning and Management, College of Environmental Science and Engineering, Tongji University 1239 Siping Road, Shanghai 200092, China

${ }^{3}$ Makerere University, P.O. Box 7062, Kampala, Uganda

${ }^{4}$ Harbin University of Commerce, No.1 Xuehai Street, Songbei District Harbin City, Heilongjiang, 150028, China

*Corresponding author details: Zhang Jing; jingzhang@tongji.edu.cn

\begin{abstract}
Zanzibar is a semi-autonomous region of Tanzania located in the Indian Ocean with the 1.6 million inhabitants heavily reliant on the ocean resources for income and livelihoods, which approximately accounts for $30 \%$ of GDP and employ about one third of the population, Zanzibar's wealth is created, not inherited. In 2020, the government formulated a comprehensive road map to formulate a blue economy policy. The economy that combines the economic, social and environmental benefits of the ocean, it is also regarded as an alternative development paradigm. Zanzibar's poverty reduction and economic growth will be dependent on the long-term management of the country's natural resources, especially the coastal and marine ecosystems, despite its clear economic importance, the marine ecosystem is seriously degraded due to both human and natural causes; uncontrolled tourism development, rapid population growth and climate change. After several reviews from different sources the blue economy concept is regarded as a way to follow up and it seems to ensure promising life to the people of Zanzibar and the environment of the island at large. However, to achieve all of this, there is need to acquire strong political willingness, commitments, rigorous researches and promoting social awareness.
\end{abstract}

\section{Keyword: blue economy; marine ecosystem; oceans; sustainable development}

\section{INTRODUCTION}

Oceans cover $72 \%$ of the surface of our blue planet and it provides a large portion of the global population with food, livelihoods and are the means of transport for $80 \%$ of global trade ${ }^{1}$.Life originated in the oceans and they continue to support all life today by generating oxygen, absorbing carbon dioxide, recycling nutrients and regulating global climate and temperature ${ }^{2}$.

We are in inflection point in history now that we no longer look ocean solely for protein and waterways but also as a source for many aspects of our increasingly industrialized society, helps to drive economic growth, social prosperity and environmental protection therefore holds a great promise for contributing towards achieving the UN 2030 Agenda and the Sustainable Development Goals (SDGs) ${ }^{3}$.
The annual gross marine products of the oceans totals $\$ 2.5$ trillion per year in 2020 to the global economy ${ }^{4}$. Contempt the fact that World has not yet developed the full potentials of the resources from the ocean, unsustainable human activities are continuing to significantly threaten life under water and the resilience of aquatic ecosystems, the resources that collective determination and building efforts at the local, national and international levels together with the global local community has to intensify investments and harness the full potential of oceans and rivers to accelerate economic growth, create jobs and to fight poverty 5 .

Since its introduction after the United Nations (UN) Conference on Sustainable Development on Rio+20 in 2012, 
Blue Economy is rapidly emerging as development paradigm that provides solution to the limits of growth6. It is a broad concept that encompasses wide variety of issues relating to ocean and coastal economy ${ }^{7}$.

The blue economy, also known as the marine economy, is an ecosystem of economic activities based on trade and actions in and around large bodies of water, such as rivers and oceans, that are controlled to ensure environmental sustainability, fishing, waste management, hospitality (beachside hotels and bars), power (offshore wind and tidal energy), and transportation are all part of the economy ${ }^{8}$.

World bank defines Blue economy as a Sustainable use of ocean resources for economic development, better livelihoods, and employment while maintaining the conservation of the ocean environment ${ }^{9}$.The World Bank further highlighted that, for an activity to successfully be one of the blue economy components need to provide social and economic benefits for current and future generations, restore, protect and maintain the diversity, resilience, core functions, and intrinsic value of marine ecosystems and be based on clean technologies, renewable energy, and circular material flows that will reduce waste and promote recycling of materials ${ }^{10}$.

As an Island state, Zanzibar's socio-economic development is heavily reliant on the sea, coast, and marine resources. By amount, seaborne trade accounts for $98 \%$ of Zanzibar's foreign trade. These blue activities account for about $29 \%$ of Zanzibar's gross domestic product.one-third of the population is employed by the gross domestic product (2019) ${ }^{11}$

The sea-based economy, also known as the blue economy (BE), is not a new economic phenomenon in Zanzibar. For centuries, Zanzibar has relied on domestic and foreign ocean-based economic activities. Zanzibar was already a regional commercial hub by the 15 th century, according to evidence because of the abundance of spices and fishery products traded internationally through long-haul seaborne trade routes along the Swahili coast and the Indian Ocean, particularly with the Arab world and within East Africa ${ }^{12}$

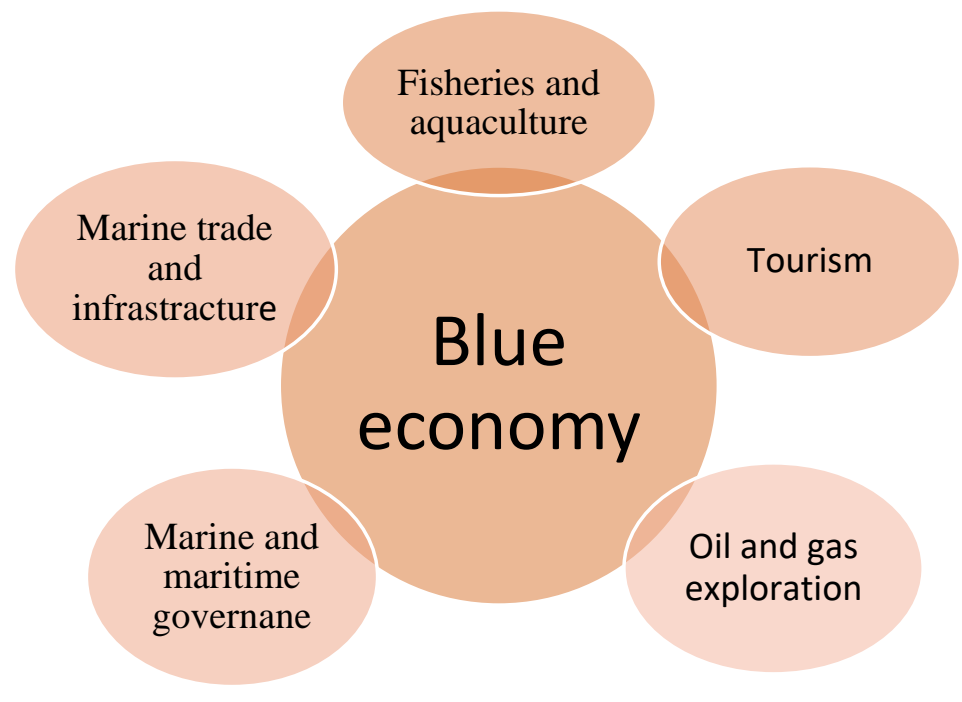

FIGURE 1: Blue economy's priority areas in Zanzibar. Source: Zanzibar Planning Commission

\section{STUDY AREA}

Zanzibar is a semi-autonomous region of Tanzania located in the Indian Ocean, 25-50 kilometres (16-31 mi) off the coast of Mainland Tanzania, it consists of two main islands which is Unguja and Pemba. ${ }^{11}$. The Islands are the home to numerous endangered and rare corals, fish, seagrass, mangroves, and other flora and fauna. Its 1.6 million inhabitants are heavily reliant on the marine environment, which accounts for $30 \%$ of GDP in (2019) ${ }^{13}$.

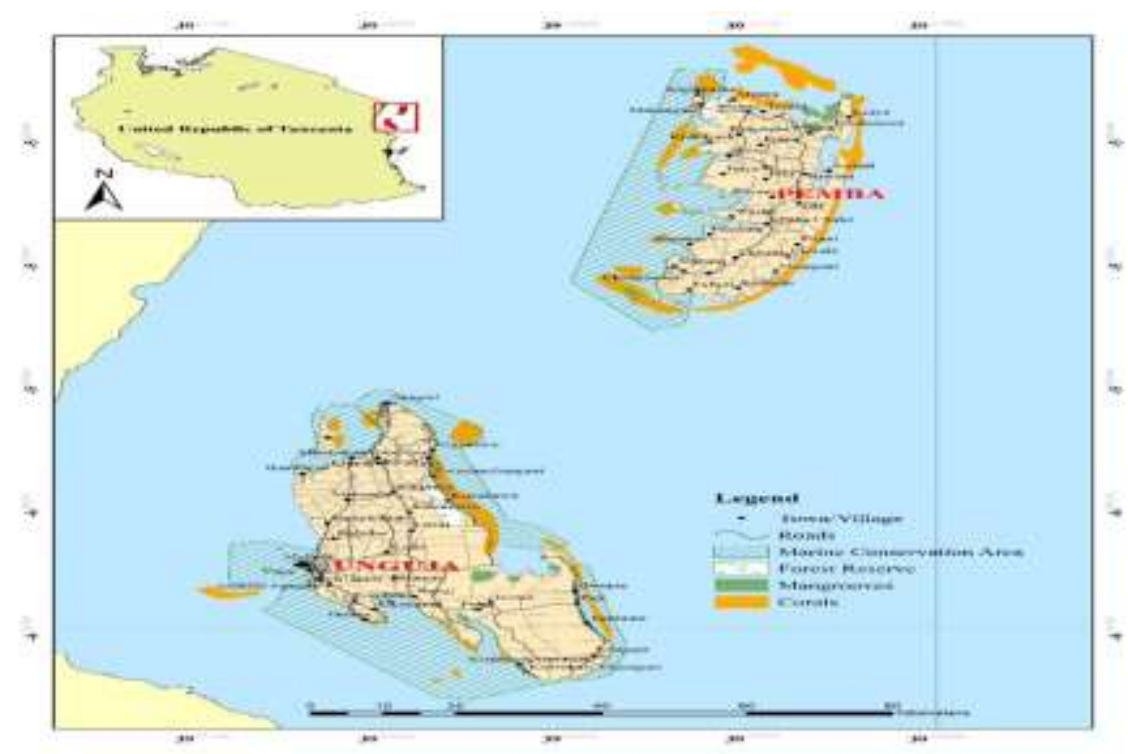

FIGURE 2: locations of Zanzibar in Indian Ocean. Source: Author 


\section{MATERIALS OF STUDY}

In order to achieve the objectives of this paper, the general review has been conducted to various literatures relevant to study that involves national legislations, policies, work reports, different research journals and other relevant works.

\section{POTENTIALS AND CHALLENGES OF BLUE ECONOMY IN ZANZIBAR}

Zanzibar carry all the necessary features like most Small Islands Development States (SIDS) for attaining a rapid economic development through the Blue economy model which is widely adopted by International organizations including World Bank and the United Nations Organizations. The successful application of the Blue economy concept in some European and Indian Ocean Rim Association (IORA) countries offer some assurance and prospects to policy makers that Zanzibar can benefit from Blue economy model. Be activities are intended to provide more realistic opportunities for the Zanzibar economy to diversify and protect itself. Local communities have not completely benefited from these opportunities, despite strong economic development, favorable investment policies, and the liberalization of the trade market. The Blue economy model can assist policy makers in Zanzibar to address the identified challenges facing SIDS including small domestic markets and limited export volume and environmental sustainability. ${ }^{14}$.

\section{Marine Fisheries and Aquaculture}

Fisheries sector contribute to national economy of the Zanzibar both in terms of income and employment. The sector employs about 49,332 small scale fulltime fishers directly and about 4,000 people are involved in other fisheries related activities such as fish processing, fish marketing, fish trade, boat building and maintenance and fishing gear mending 15 . The fishing activities are mostly artisanal with a small semi-industrial component which taking place within internal and territorial waters (12 nautical miles). The estimated size of fishing grounds for Zanzibar artisanal fishermen is about 6,720 square kilometers of which 4,000 square kilometers $59 \%$ are around Unguja and 2,720 square kilometers 40.5\%are around Pemba 14 . Total exports of fish and fishery products were valued at USD 158.7 million in 2015 and imports at USD 17.4 million while the annual per capita consumption of fish was estimated at about 7.2 kilograms 16 .

Temporarily aquaculture is dominated by seaweeds as a well-established industry in Zanzibar; seaweed farming has created more than 25,000 jobs for the indigenous people where by $80 \%$ of them are women. Zanzibar is the third largest exporter of seaweeds in the World, after the Philippines and Indonesia. There are two main seaweeds species cultured I Zanzibar which is Eucheuma spinosum and Eucheuma cotton, Eucheuma spinosum is a dominant specie as it grows out through the year and in almost all area of Zanzibar while Eucheuma cotton can grow in some parts of the Islands oceans and in some months of the year (usually during cool periods) ${ }^{14}$.

\section{- Potentials of Marine Fisheries Sector}

Zanzibar has deep sea and offshore fishing investment and currently local artisanal undertaking, specially reserved for citizens only. By welcoming more investors, it could increase national income and provide employment in many rural areas where there are insufficient opportunities. Despite being surrounded by water, Zanzibar remains far from successfully exploiting her Godly endowed marine resources.

An inadequate fishing activity especially for tuna which stays in the deep sea where by its accessibility is limited due to lack of facilities to go to offshore fishing. ${ }^{17}$. Zanzibar's maritime area is larger than its land area: United Republic of Tanzania's Exclusive Economic Zone(EEZ), of which Zanzibar is part, has an area of 241,541 square kilometers, making it 91 times larger than Zanzibar's land area of 2,654square kilometres ${ }^{12}$.This means that there are a lot of untapped sea-based resources off the coast of the Zanzibar thereby reinforcing the need to harness the sea through BE to alleviate poverty and create employment, boost growth and exports, and enhance food and energy security

\section{- Challenges for fisheries Sector}

Unsustainable fishing practices: the artisanal fishery along the coastal villages of Zanzibar is under high pressure from use of destructive fishing gears and this has contributed directly to the deterioration of coral reefs conditions in most part of the Island which endanger the life of many fish species $^{18}$.

Shortage of suitable infrastructure and equipment: Zanzibar has the geographical advantages being constructed into the East and Central Africa-if not the continental hub-for fishing and fish processing, unfortunately, it is not. Lack of modern fishing tools and methods makes fishers to mostly operate in inshore waters of the Islands. This situation cause highly degradation of fish community as there is high capture of immature fishes which violate the laws and regulation ${ }^{18}$. Only 15.6 percent of fishing vessels in Zanzibar were powered by engines, according to a 2010 fishing census, with the majority using sails, poles, and/or paddles ${ }^{12}$. Since cooling facilities for storing fish are limited, the majority of the catch must be sold on the day of capture, offering no protection to fluctuating or low prices. However, despite the large local demand of fish, distribution of fish to consumers is faced with some constraints including weak marketing channels and lack of storage facilities. This decreases the value of fish and may lead to some physical and economic post-harvest losses.

Meanwhile, the price of fish is steadily increasing which may reflect the scarcity of the supply and the increased demand of fish, particularly from the tourism industry ${ }^{19}$.

Lack of investment in Fisheries industries which makes Zanzibar not be fully benefited from sea resource that surround the Islands, for example in 2019 only one project out of 37 approved investment project was on fishing sector ${ }^{20}$

TABLE 1: List of approved investment project in Zanzibar for 2019

\begin{tabular}{|l|c|c|c|}
\hline Sector & $\begin{array}{c}\text { Approved } \\
\text { Project }\end{array}$ & $\begin{array}{c}\text { Approved capital } \\
\text { (USD) }\end{array}$ & Approved employment \\
\hline Agriculture hunting and forestry & 4 & 3,409 & 97 \\
\hline Fishing & 1 & 1,000 & 20 \\
\hline Manufacturing & 8 & 7,560 & 3,193 \\
\hline Wholesale and retail trade & 3 & 3,400 & 1,387 \\
\hline Hotels and restaurant & 17 & 350,985 & 36 \\
\hline Transport storage and Communication & 1 & 20,0090 & 16 \\
\hline Real estate renting and Business activities & 2 & 7,700 & 47 \\
\hline Health and Social work & 1 & 700 & 4 \\
\hline
\end{tabular}




\section{Seaweed Production}

\section{- Potential of Seaweed production}

Seaweeds come third followed only by tourism sector and cove farming. During its peak, seaweeds farming contributes about USD 6 million annually to Zanzibar's economy and in term of value to the national economy, Seaweeds from Zanzibar is exported to China, Denmark, France, The Republic of Korea, Spain, Vietnam and the United State of America. ${ }^{21 .}$
- Challenges face Seaweed production in Zanzibar

Climate change: However, the industry struggles to remain a major player currently large swathes of seaweed are dying, attributed by researchers to high temperature conditions as a result of climate change, important climatic variables that have affected seaweed include increasing of water temperature, wind speed, sea waves and a decrease and irregular in rainfall patterns and salinity ${ }^{22}$.Deeper water culture is one solution, although about 90 percent of Zanzibar's seaweed farmers are women and traditionally, they do not swim. Since the seaweed farmers are most vulnerable to the impact of climate change, 22 .

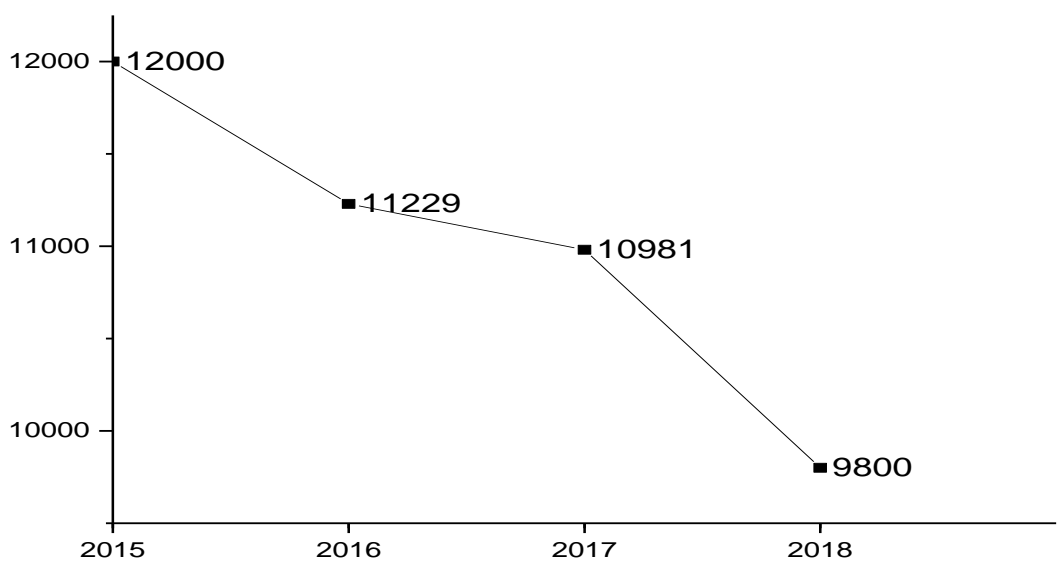

FIGURE 3: Seaweed production chart from 2016 to 2018. Source: Ministry of Blue economy and Fisheries -Zanzibar.

More over Many farmers have adopted unsustainable farming practices, accidentally degrading the aquatic resources upon which their livelihoods depend. The most common cultivation method is so-called off-bottom peg and line method where by the farmer's plant two stakes into the sea floor, between which they suspend the seaweed on ropes. However, they have been cutting down mangroves for these stakes leading to the deforestation of fish spawning grounds and sometimes the farms also cover sea grasses or create plastic and other marine debris ${ }^{23}$.

\section{Tourism}

Zanzibar tourism sector accounts for 27 percent of country's GDP and over 80 percent of foreign currency earnings, while employing over 75,000 people, it is the leading private sector job creator as the one of the fastest growing industries in Zanzibar has attracted more than 68 percent of investment projects approved by Zanzibar Investment Promotion Authority (ZIPA) ${ }^{24}$. The sector boasts a wide variety of tourism options ranging from the historical and cultural sites of Old Stone Town, to beach and leisure activities with more emphasis on eco-tourism opportunities exist in hotels/resorts specifically chain hotels and sports tourism. Some other potential fields of tourist attraction that are directly or indirectly linked to coastal tourism are health tourism, heritage tourism, marinas, special cuisine restaurants, sports activities, amusement and recreation activities.

\section{- Challenges for Tourism Sector}

Waste Production: Zanzibar's tourism sector has grown rapidly in recent years, registering 13\% year-on-year growth on average, in international visitor numbers over the past four years. The number of international visitors has grown over the last 30 years, from about 18,000 in 1985 to 520,809 in $2018^{25}$.Unprecedented growth of the tourism industry brought about an enormous increase in waste generation that shifted from organic materials to recyclables and hazardous waste derived from large tourism enterprises yet the input accumulations of plastic materials generated by these sectors remained not surveyed.

The report shows tourists do produce much more waste than locals as it is calculated that tourists in Zanzibar generate two bottles of 1.5 liters per day, which means a total of 5 million plastic bottles per year of which each will take in average 450 years to biodegrade in nature without treatment or proper waste management. The (expected) growth of tourism has contributed significantly to the plastic waste in Zanzibar ${ }^{26}$.Of the total amount of plastics produced in Zanzibar, only approximately $100 \mathrm{~kg}$ are collected and recycled every week, this is equivalent to only $9 \%$ of all plastics waste generated by hotels. ${ }^{27}$. An un quantified amount is dispersed in the environment and coastal waters where it may persist for centuries; this situation has an effect to the marine ecosystem, marine littering cause's serious economic damages by affecting a wide range of natural environments that are considered primary ecotourism attractions. 


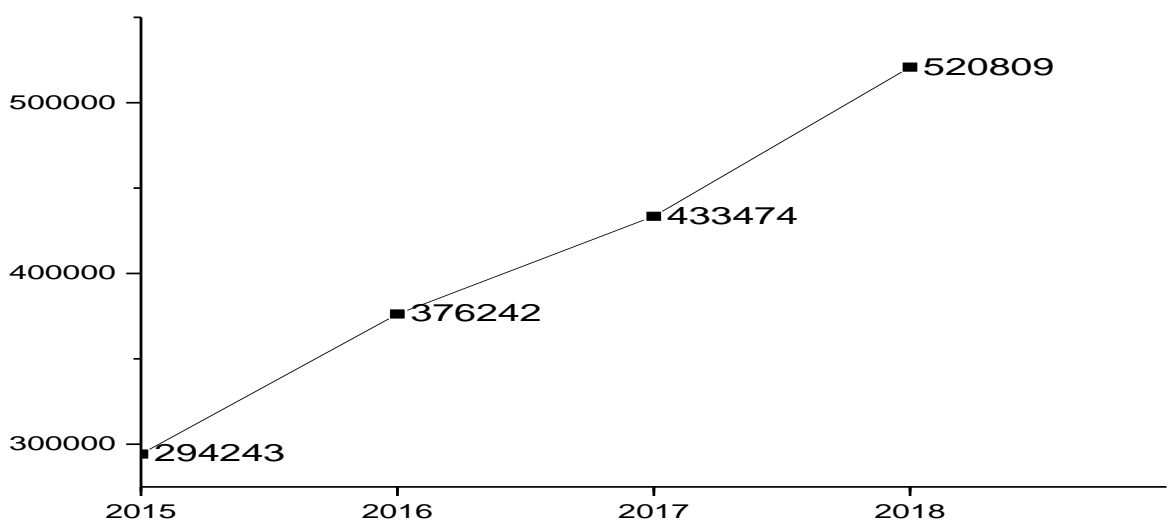

FIGURE 4: A chart of number of tourists arrived in Zanzibar between 2015 and 2019. Source: Zanzibar Commission for Tourism (2020).

\section{Maritime Sector}

The Maritime industry has traditionally and historically played a major role in Zanzibar economic and social development. The industry still plays an instrumental role and critical to the current and the future economic development as well as the overall competitiveness of Zanzibar ${ }^{28}$. Over 98 per cent of Zanzibar international trade passes through the seas. Furthermore, maritime sector offers plenty of opportunities for Zanzibar to grow through blue economic initiatives as it consists of a wide range of inter-connected strategic industries include shipping, ports, fishing, service suppliers as well as coastal maritime tourism. They all contribute considerably to the economy of Zanzibar, thus the strategic importance of managing and regulating maritime transport sector in an efficient and effective way ${ }^{29}$. Zanzibar has a maritime transport system which provides links between the country's principal islands and to the mainland and beyond. There are five official ports in Zanzibar namely Malindi, Mkokotoni, Mkoani, Wete, and Wesha ${ }^{28}$.

\section{- Potentials}

The strategic geographic location of Zanzibar confers comparative advantage on the island, but to exploit this advantage in trade requires the island to possess some strategic product and services with which to engage in trade. In this context, there is need to promote and exploit sea transportation services for which it can build and maintain comparative and competitive advantages. ${ }^{29}$.

Additional if the the provision of container storage space is will be expanded and upgraded, to have a sizeable inland container depot Zanzibar economy will witness more growth through the sector. It is reported that Malindi Port at a competitive disadvantage to its regional rivals, notably Mombasa Port in Kenya. Malindi Port handled about 80,000 TEUs of cargo in 2019 compared to 940,000 TEUs passing through Mombasa in the same year ${ }^{30}$.

\section{- Challenges}

The high cargo traffic between important trade routes in the area, such as Malindi-Dar es Salaam, Unguja-Pemba and Pemba-Mombasa, suggests that there is a risk of fuel leakage from cargo ships, in 2016 an oil spill occurred in Pemba, when the high tide caused a hole in the hull of a ship, leading to a discharge of white petroleum ${ }^{12}$. Specific and appropriate mitigating strategies are required as frequent oil spills like this can threaten the marine ecosystem due to their toxicity.

\section{Oil and Gases exploration}

The Pemba-Zanzibar block has a proven hydrocarbon system, as evidenced by the Tundaua oil seep on Pemba Island and oil shows in previous exploration wells. Multiple source rocks and petroleum reservoirs are anticipated and numerous prospects have been mapped. The exploration for oil and gas in Zanzibar is still a work in progress under a RAKGAS company of Ras Al Khaimah United Arab Emirates (UAE). In addition to that, the studies carried out in Pemba-Zanzibar block through Full Tensor Gradio metric Survey (FTG) and 2D Seismic Survey show the big possibility of availability of source and reservoir rocks that form the basis of crude oil and natural gas. The 2D seismic studies show that there are geological structures that have the capacity of storing natural gas of about 3.8 trillion cubic feet (tcf) ${ }^{31}$.

\section{- Potentials}

In spite of all its challenges, the oil and gas explorations will spearhead the growth of the country and its economy at large. This will occur through improved infrastructure (roads, commercial buildings, telecommunications), employment opportunities with petroleum companies or their contractors and service providers, improved water supply (wells, boreholes brought closer to communities), improved sewerage and waste management (waste disposal), better health care and education services (schools, hospitals, scholarships).

\section{- Challenges}

Being an emerging sector in Zanzibar and viewed as a big contribution to the growth of blue economy, the oil and gas exploration activities have the potentials for variety of impacts on the environment, the kind and level of impacts are dependent on the stage of the process, the size and complexity of the project, the nature and sensitivity of the surrounding environment, and the effectiveness of planning, pollution prevention, mitigation and control techniques. The environmental implications at the various stages of the exploration and development process can be assessed systematically before a project starts, and appropriate measures taken through appropriate management procedures.

Exploration and production operations are likely to induce economic, social and cultural changes amongst communities. The extent of these changes is especially important to local groups, particularly indigenous people who may have their traditional lifestyle affected. 
Atmospheric emissions, produced water, drilling fluids, cuttings, well treatment chemicals, domestic wastes, leaks, blowouts, and oil spills are direct potential challenges to the environment that could have happened during exploration and production of oil and gas in Zanzibar. However, the general extent of the impact can only be judged through an environmental impact assessment (EIA).

\section{SWOT ANALYSIS}

The table below in analyzing the SWOT for Zanzibar blue economy it is shown that despite of having separate Ministry but still the sector has not been tapped to witness the full potential of the sector in social, economically and environment sustainability.

High resources potential, strategic geographical location and good regional and international collaboration give any insight that Zanzibar has opportunity to prosper through sea/ocean resources. Notwithstanding limited finance and expertise, lack of modern tools and technology and community awareness may be limiting factor meanwhile climate changes threaten the sustainability of sector in general.

TABLE 2: SWOT analysis of Zanzibar's Blue economy Sector

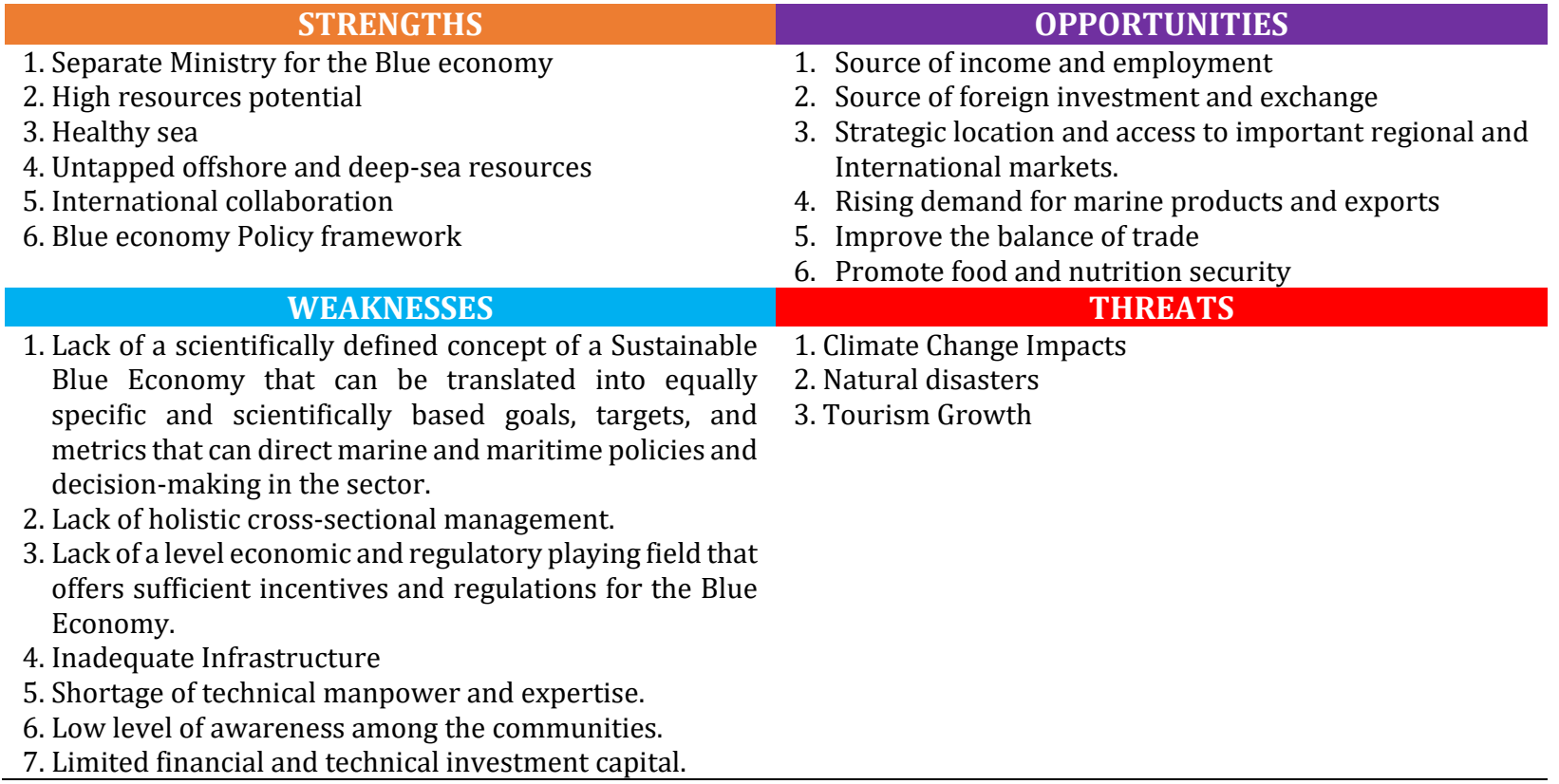

\section{ACTIONS TO SUPPORT BLUE ECONOMY IN ZANZIBAR}

The growth of the blue economy requires a range of framework conditions to be fulfilled. Most importantly, the following are key interlinked enablers that are vital for catalyzing blue investment and growth.

\section{Ocean Governance}

As governments encourage the economic development through ocean, comprehensive and integrated approaches that recognize the interactions between and the interdependent natures of the various ecosystems, both terrestrial and marine. The Maritime Spatial Planning is among the best approach in helping get to the Sustainable blue economy, various countries have started to use marine spatial management to achieve sustainable use and biodiversity conservation in oceans and coastal areas.

MSP provides a way to integrate human activities without compromising conservation values, through MSP the stakeholders can put forward their vision for an area by identify where human activities (including offshore energy, shipping, fishing, aquaculture, tourism, and mining) currently occur and where it might be desirable for them to occur in the future and identify actual or potential conflicts between different oceans related uses and human activities and desired conservation outcomes the resulting spatial plan can provide for sustainable use ${ }^{32}$

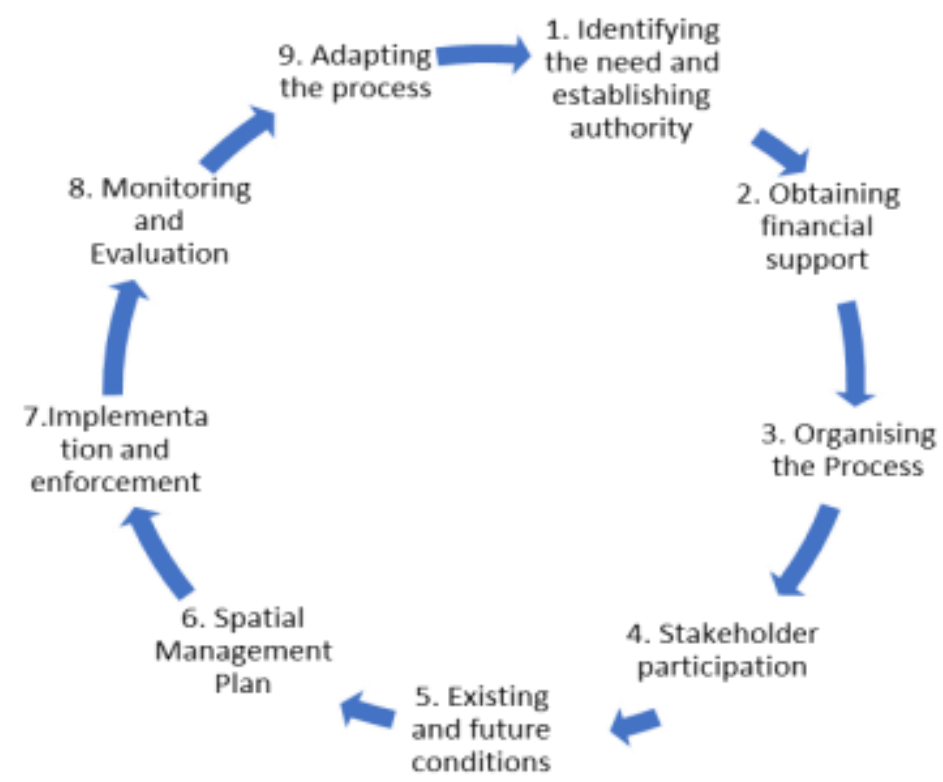

FIGURE 5: Marine Spatial Planning Cycle. Sources: (Association, Western Indian Marine Science; CSIR2017) 


\section{Education and capacity building}

A lack of education and training in marine management has led to chronic technical gaps in marine planning and decision-making. By identifying future skills needs and labor market supply and demand trends, and adapting and developing existing education. A vocational land professional training programs to improve capacity in these areas will be essential if the blue economy is to become a reality. Knowledge of the marine environment is also critical for effective decision-making, the more the Islands know about the marine environment, and the better they can manage human interaction with oceans. Integrating diverse and complex information, and supplementing it with new research, will contribute to the advancement and management of ocean resources ${ }^{33}$.

\section{A healthy, resilient and productive marine environment}

The health of coral reefs and the biodiversity that they provide are of critical importance, both from an environmental and from an economic perspective this is because of the heavy reliance of these states on tourism and fisheries. Therefore, effective management of the marine environment and the maintenance and restoration of ecosystem health and integrity is fundamental to ecologically sustainable development ${ }^{33}$.

\section{Infrastructure and Technology}

Investments in capture fisheries and aquaculture have to be supported by investing in infrastructure. Some of these include ice making plants, cold storage facilities and processing industries. Despite fisheries being among the dependent sector, The Islands of Zanzibar don't have even a single fish processing plant ${ }^{34}$. Coastal and port infrastructure is critical for catalyzing economic growth and development in the Islands like Zanzibar, given its heavy reliance on marine ecosystem. In addition to that taking advantage of the advanced science and technologies that can offer new solution such as mobile technology that allows for better data on fish landings and fish stock health.

\section{Maritime surveillance, monitoring and enforcement}

The effective management of ocean space and future economic growth depends on a robust maritime regulatory regime combined with an effective and efficient surveillance and enforcement system. Although legal frameworks for many marine activities exist weak enforcement is an ongoing challenge ${ }^{33}$. There are needs to have strong monitoring and enforcement system so as the any activities undertaken is done in sustainable way.

\section{Business development, investment and finance}

Sustainable financing mechanisms that will provide longterm and reliable funding to support blue economy activities will help into realizing the potential of it towards achieving SDGs goals, those activities including conservation and sustainable management initiatives for marine and coastal resources as well as the wider environment.

A range of innovative finance mechanisms exist that could be applied to a variety of initiatives, including fishery improvement projects, habitat restoration and protection projects, valorization of a range of marine ecosystem service values and projects that link coastal and marine ecosystems to climate change adaptation.

For Zanzibar in particular, the greatest potential for value addition and job creation lies with the development of small and medium-sized enterprises (SMEs) within blue economy value chains. Finance for SMEs will therefore be an important enabling factor, as these entities can catalyze job creation and economic growth. There is, therefore, a need to examine mechanisms to encourage start-up SMEs and to assist with capacity and technology development ${ }^{33}$.

There is a need to invest more in human capital, lack of technical expertise and a shortage of experienced personnel will be one of the major challenges in adopting the blue economy. Zanzibar needs to invest in up skilling Zanzibar is youths to capitalize on the opportunity brought about by the ocean and growing global maritime industry, jobs created from the sector include; shipbuilding experts, marine equipment experts, seaports and related services, recreational boat experts, coastal tourism, deep-sea fishing, offshore oil, and gas extraction, offshore and coastal wind energy, etc.

Public Private Partnership (PPP) is important in realizing the blue economy, having shared projects can help in promoting the sector. This initiative would assist in developing national regulatory regimes and approaches that include economic instruments (pollution taxes, payment for ecosystem services, etc.), the creation and dissemination of research, tools, capacity building, buy-in from industry and transition towards a blue economy.

\section{CONCLUSIONS AND RECOMMENDATION}

Blue Economy is increasingly being proposed by scholars and policy makers as a blueprint for promoting economic development aimed at GDP growth, poverty reduction (income and employment) and a concept for conserving the world's ocean and the inherent resources.

Oceans hold vast economic development potential, but they are also fundamental to maintaining human life on this planet. Fortunately for us, economic growth does not require environmental degradation. In fact, protecting fully functioning marine ecosystems may be the smartest investment of capital that we as a society can make.

The way forward is an economic development of the oceans that is both comprehensive and environmentally stable ought to be undertaken in a way that does not drain the natural resources that societies including local communities rely upon in the long term. To balance the economic, social and environmental dimensions of sustainable development in relation to oceans are the driving considerations behind Blue economy.

To sum up, the potentials for the Zanzibar to succeed in Blue economy are boundless but to achieve long-term sustainable prosperity needs political commitments, plenty of researches, societal awareness

\section{DISCLOSURE STATEMENT:}

No potential conflict of interest was reported by the author(s).

\section{REFERENCES}

[1] FAO, World Review of Fisheries and Aquaculture, Rome Italy, pp. 52-62, 2012.

[2] Hassan et al, The Prospects of Blue Economy to Promote Bangladesh into a Middle-Income Country. Journal of Marine Science, 8, 355-369, 2018.

[3] Golden J. et al, making sure the blue economy is green. Journal of nature ecology and Evolution 2017, 1 (2), 1-3.

[4] https://www.weforum.org/agenda/2020/06/humanimpact-ocean-economy retrieved on April 2021.

[5] United Nation, Working Group Proposal for Sustainable Development Goals, available at: https:// sustainable development.un.org/, 2014. 
[6] Bohler N., The Blue Economy Handbook of the Indian Ocean Region, Pretoria: Africa Institute of South Africa, p. 12018

[7] Mostaque M, Blue Economy and Bangladesh: Lessons and Policy Implications BIISS JOURNAL, VOL. 39, NO. 2 2018.

[8] Awoyemi 0., The Blue Economy: Thoughts to Action, pro share economy journal, 2019.

[9] Patil, P.G. et al, Toward A Blue Economy: A Promise for Sustainable Growth in the Caribbean; An Overview. The World Bank, Washington D.C. 2016.

[10] Hamisu H, "A study of Nigeria's blue economy potential with particular reference to the oil and gas sector" (2019). World Maritime University Dissertations. 1234 https://commons.wmu.se/all_dissertations/1234

[11] Office of the Chief Government Statistician Zanzibar. https://www.ocgs.go.tz/ retrieve on 12th September 2020.

[12] Revolutionary Government of Zanzibar, Blue economy Policy, 2020.

[13] Jiddawi N and Lange, G, Economic value of marine ecosystem services in Zanzibar: Implications for marine conservation and sustainable development. Ocean \& Coastal Management 52 (2009) 521-532 2009.

[14] Mfamau M, Blue economy in Zanzibar: Policies and Priorities. Global Issues and Local Actions in SouthSouth Cooperation 2019.

[15] Jiddawi and Ohman, Marine Fisheries in Tanzania Institute of Marine Sciences, University of Dar es Salaam, Zanzibar, 2002.

[16] FAO, Zanzibar mariculture leaps forward. 2018

[17] Masato M., Zanzibar Turns Focus to Untapped Blue Economy. 2020.

[18] Jiddawi N and Yahya S., Zanzibar Fisheries Frame Survey. Department of Fisheries and Marine Resources, M. o. A., Natural Resources and Cooperatives, Zanzibar Institute of Marine Sciences, University of Dar es Salaam. 2003.

[19] The Revolutionary Government of Zanzibar, Zanzibar Fisheries Policy. 2014.

[20] Office of Chief Government Statistician - Zanzibar, Zanzibar in Figure. 2019.
[21] FA0, The global status of seaweed production, trade and utilization: FAO Globefish Research Programme VOL. 1242018.

[22] Hassan I. and Othman W., Seaweed (Mwani) Farming as an Adaptation Strategy to Impacts of Climate Change and Variability in Zanzibar. Springer, pp 5368.2019 .

[23] Hashim N, Revisiting Zanzibari Seaweed: Global Climate Change - Mitigation and Adaptation. (Independent Researcher, USA) 2019.

[24] Zanzibar Commission for Tourism. http://www.zanzibartourism.go.tz/ retrieved on 13 September 2020.

[25] Revolutionary Government of Zanzibar, Tourism Integrated Strategic Action Plan. 2018.

[26] UNICEF, Assessment of the Impact of Tourism on Communities and Children in Zanzibar. 2018.

[27] Maione C., Emergence of plastic pollution on tourism beaches in Zanzibar, Tanzania. Master's Thesis School for Environment and Sustainability, University of Michigan 2019.

[28] Zanzibar Maritime Authority, Strategic \& Business Plan 2016.

[29] Ministry of Infrastructure, Communication and Transportation, Zanzibar Maritime Strategy for Implementing IMO Instruments 2019 - 2023. 2019.

[30] Africa Port, Port of Mombasa (online) available at https://africaports.co.za/mombasa/accessed on 10th April 2021.

[31] OG link, Exploration on gas and oil in Zanzibar has come to an end available at https://oglinks.news/uae/news/exploration-ongas-and-oil-in-zanzibar-has-come-to-an-end. 2019. Accessed on 20th March 2021

[32] Nairobi Convention Secretariat, Western Indian Ocean Marine Science Association \& CSIR, A Case for Marine Spatial Planning in the Blue Economy of the Western Indian Ocean. 53pp. 2017.

[33] Julian R and Ahmed A, The Blue Economy in Small States. Small States Digest Issue 1, 2016.

[34] eafrica/zanzibar-in-plans-to-develop-its-fishingsector-1435256 retrieve on February 2021. 